\title{
How medical schools can better support students who are parents
}

\author{
n Cite as: CMAJ 2019 February 25;191:E243-4. doi: 10.1503/cmaj.109-5707
}

Posted on cmajnews.com on Feb. 7, 2019.

E lise Thorburn, a first-year medical student at Memorial University of Newfoundland, is in her midthirties and has a five-year-old daughter. Though she pursued her dream of becoming a doctor after already completing a PhD, "I was not prepared for how incredibly hard it is," she said.

It is not uncommon for her to spend 14 hours a day learning and studying. "I go home so I can see my partner and my daughter, and give them a kiss, and then I'm back to the library," she said. Her daughter tells her that she misses her but also that she's proud of her. "She thinks it's pretty awesome that I'm doing this." Her one wish for her medical school: childcare on campus, so she could pop in and see her daughter during breaks.

Medical schools don't collect data on how many of their students have children, but the Canadian Federation of Medical Students (CFMS) recognized the need to address the topic after a growing number of requests from students, according to Victor Do, director of student affairs at CFMS.

"The policies [on parental accommodation] are inconsistent," said Do. Most students can take a year of parental leave, but policies are unclear about the impacts on graduation, start and end times, as well as whether financial aid is suspended during leaves, according to the CFMS paper Support of Parents in Undergraduate Medical Education. In addition to pushing for standardization of parental leaves, CFMS is advocating for nationwide policies on breastfeeding, childcare and more.

Do said the parents he sees perform at or above average in courses and clinical work and are not asking for a lighter load,

but rather fair accommodations. For example, parents should have preference of choice for clerkship placements in rural sites, as they may need to move their children as well, according to Do. CFMS is also calling for universities to give medical students priority for on-campus childcare spots. Some schools, including Western University, already do this but it isn't a given at most schools.

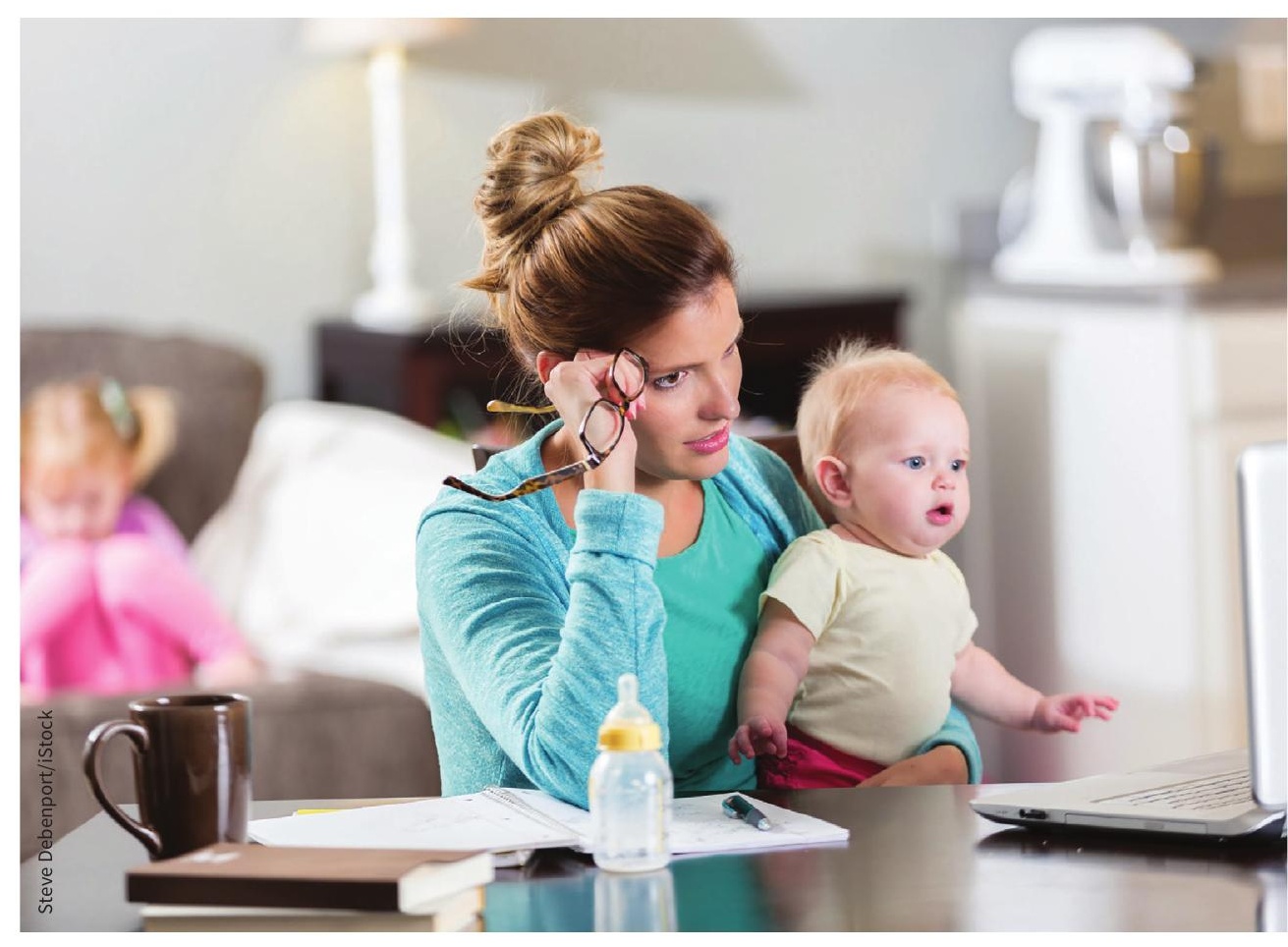

Medical students with young children have few hours to spare.

Ameer Jarrar, a third-year medical student at Dalhousie University, is one of five parents in his class. He notices the parents aren't "as involved in social activities as everyone else," but he thinks the time he spends with his daughter helps to counter burnout because she helps him forget about his studies. "When I do get to spend the time with my daughter, I want to maximize it and make it as meaningful as possible, so I help her with schoolwork, tell her stories or go out with her," he said. His daughter also "adds meaning" because "in a way, I know she's going to reap the benefits of the struggle."

Dr. Margo Mountjoy, a regional assistant dean of medicine at McMaster University, acknowledges that parenting in 
have very good references." One way that parents at medical school tend to stand out is in their clinical skills, and other students take notice, said Mountjoy. "Parents have experience talking to someone and being patient and calm and pulling out answers from reluctant people," she said.

Another parenting skill that translates well to clinical work is multitasking. "We're used to listening to someone talk, while cooking, while packing a lunch," said Thorburn.

And like Jarrar, she sees how being a parent can help stave off burnout. "I don't go home to a lonely house and have to cook myself dinner," she said. At the same time, she feels "stretched in a lot of directions," and worries that she can't fill out her resume with extracurricular activities like other students, which is becoming more important "because of how competitive it can be to get residency positions."

Fortunately, medical students who are parents can now support each other and advocate for changes via a national student-parent network, launched last year by CFMS.

In addition to standardized leave policies and preference in clerkship choices, CFMS is calling for greater flexibility in medical school curricula to accommodate parents better. Its position paper points to the example of Brown University, where pre-clerkship courses are offered in sixweek periods, allowing students to schedule short-terms leaves into their schedules instead of having to take an entire year off. Another suggestion for increased flexibility is recorded lectures to allow parents to catch up on missed content.

"Parents are very hard working," said Do. "They're making us think more about accommodations, which are important for everyone, including students with disabilities, and they're making us more cognizant of work-life balance, which will be important for us to think about throughout our careers."

Wendy Glauser, Toronto, Ont. 